Akreditasi KEMENRISTEKDIKTI, Nomor: 148/M/KPT/2020
Volume 12 Nomor 1, April 2021, Halaman 104-113
http://ijurnal.stkippersada.ac.id/iurnal/index.php/vox

\title{
EVALUASI PELAKSANAAN PEMBELAJARAN DARING DI INDONESIA SELAMA MASA PANDEMI COVID-19
}

\author{
Jumardi Budiman \\ Fakultas Keguruan dan Ilmu Pendidikan, Universitas Tanjungpura \\ Email: jumardib@fkip.untan.ac.id
}

\begin{tabular}{|c|c|}
\hline INFO AI & RTIKEL \\
\hline Riwayat A & rtikel: \\
\hline Menerima & : 03 Maret 2021 \\
\hline Revisi & : 11 April 2021 \\
\hline Diterima & : 14 April 2021 \\
\hline
\end{tabular}

Kata Kunci:

Evaluasi, pembelajaran, dalam jaringan, pandemi covid-19

Keywords:

Evaluation, learning, online, the covid-19 pandemic

Korespondensi:

Jumardi Budiman

FKIP Universitas Tanjungpura

Email:

jumardib@fkip.untan.ac.id

\begin{abstract}
ABSTRAK
Pandemi covid-19 membuat sistem pembelajaran di Indonesia yang berlangsung secara klasikal berubah menjadi pembelajaran dalam jaringan (daring). Tujuan penelitian ini yakni mengevaluasi pelaksanaan pembelajaran daring di Indonesia pada masa pandemi covid-19. Metode penelitian menggunakan studi kepustakaan dengan sumber data berupa artikel ilmiah yang membahas tentang pelaksanaan pembelajaran daring selama masa pandemi covid-19. Teknik analisis data menggunakan analisa kualitatif yakni reduksi data, penyajian data dan verifikasi/ penarikan kesimpulan. Temuan dalam penelitian ini bahwa mekanisme pembelajaran daring memiliki dampak positif berupa kemandirian siswa dalam belajar, peningkatan aktivitas mencari sumber belajar dan inovasi gaya belajar. Dampak negatif pembelajaran daring berupa rasa jenuh dan penurunan minat belajar akibat kegagalan siswa dan guru dalam mengatasi kendala seperti sarana penunjang yang tidak memadai, ketiadaan kuota internet dan sinyal internet yang buruk. Tantangan yang dihadapi oleh siswa dan guru selama pembelajaran daring yakni ketersediaan sarana penunjang, strategi pembelajaran yang inovatif dan sinergi ntara komponen pendidikan. Pembelajaran daring berpeluang untuk terus dilaksanakan dengan system blended learning guna menciptakan ekosistem pembelajaran digital yang efektif dan efisien.
\end{abstract}

\section{ABSTRACT}

Pandemic covid-19 makes the learning system in Indonesia that takes place classically turned into online learning. The purpose of this study is to evaluate the implementation of online learning in Indonesia during the Covid-19 pandemic. The research method uses library research with data sources in the form of scientific articles that discuss the implementation of online learning during the Covid-19 pandemic. The data analysis technique uses qualitative analysis, namely data reduction, data presentation and verification I conclusion. The findings in this study are that online learning mechanisms have a positive impact in the form of student's independence in learning, increased activity to find learning resources and innovation in learning styles. The negative impact of online learning is in the form of boredom and decreased interest in learning due to the failure of students and teachers to overcome obstacles such as inadequate supporting facilities, absence of internet quota and poor internet signal. The challenges faced by students and teachers during online learning are the availability of supporting facilities, innovative learning strategies and synergy between education components. Online learning has the opportunity to continue to be implemented with a blended learning system to create an effective and efficient digital learning ecosystem 


\section{PENDAHULUAN}

Kasus pertama Covid-19 di Indonesia pertama kali diumumkan secara langsung oleh Presiden Republik Indonesia tanggal 2 Maret 2020 (Nuraini, 2020). Penularan virus yang sangat cepat berdampak pada peningkatan kasus positif Covid-19 secara signifikan. Rilis satuan tugas penanganan covid-19 per tanggal 2 Maret 2021 bahwa jumlah kasus Covid-19 di Indonesia telah mencapai 1,3 juta orang (Covid19.go.id, 2021). Kondisi ini sejak awal telah diprediksi oleh pemerintah sehingga pada masa awal pandemi covid-19, pemerintah Indonesia membuat kebijakan untuk memberlakukan Pembatasan Sosial Skala Besar (PSBB) guna memutus mata rantai penularan virus covid-19. Pemberlakuan PSBB ini sangat berimplikasi pada kondisi sosial ekonomi serta pendidikan di Indonesia. Kegiatan belajar-mengajar secara konvensional melalui tatap muka di sekolah, untuk sementara dihentikan demi keselamatan dan kesehatan siswa dan guru. Kementerian Pendidikan dan Kebudayaan (Kemendikbud) memutuskan untuk melakukan perubahan dalam mekanisme pembelajaran di masa pandemi covid-19 yang tertuang dalam surat edaran nomor 4 tahun 2020 (Kemendikbud, 2020). Surat edaran ini mengatur tentang proses pembelajaran yang dilaksanakan dari rumah dengan prinsip pembelajaran jarak jauh (PJJ) melalui media internet yang kemudian dikenal dengan istilah pembelajaran dalam jaringan (daring).

Terdapat empat poin penting tentang PJJ selama masa pandemi covid-19 yang tertuang dalam surat edaran tersebut. Pertama, bahwa belajar dari rumah harus mampu memberikan pengalaman belajar yang bermakna bagi siswa, tanpa terbebani tuntutan menuntaskan seluruh capaian kurikulum kenaikan kelas maupun kelulusan. Kedua, memfokuskan pada pendidikan kecakapan hidup antara lain mengenai pandemi covid-19. Ketiga, memberikan variasi aktivitas dan tugas pembelajaran belajar dari rumah antarsiswa, sesuai minat dan kondisi masing-masing, termasuk mempertimbangkan kesenjangan akses/fasilitas belajar dari rumah. Keempat, memberikan umpan balik terhadap bukti atau produk aktivitas belajar dari rumah yang bersifat kualitatif dan berguna bagi guru, tanpa diharuskan memberi skor/nilai kualitatif (Bari, 2020) .

Sejak awal ditetapkan pada bulan Maret 2020 silam, sistem pembelajaran daring telah berlangsung selama dua semester yakni semester ganjil dan genap tahun ajaran 2020/2021. Hingga saat ini, Kemendikbud belum menetapkan kepastian untuk mengakhiri sistem pembelajaran daring dan kembali menerapkan sistem konvensional mengingat jumlah kasus covid-19 di Indonesia yang terus bertambah.

Implementasi sistem pembelajaran daring di Indonesia yang telah berlangsung selama satu tahun, membawa berbagai perubahan dan dampak baik positif maupun negatif dalam proses belajar-mengajar (Simamora, 2020). Dampak positif yakni melalui pembelajaran daring, siswa dapat lebih mandiri dalam proses pengaturan diri, pemantauan diri, manajemen waktu dan merefleksi hasil belajar. Siswa juga 
diberikan keleluasaan untuk memperkaya wawasan dengan mengeksplorasi berbagai sumber belajar dan melakukan improvisasi terkait gaya belajar yang mereka sukai. Proses ini membawa dampak positif terhadap peningkatan kreativitas dan inovasi siswa (Giatman et al., 2020; Schaefer et al., 2020).

Namun demikian, beberapa hasil riset lanjutan menyatakan bahwa pembelajaran daring secara keseluruhan selama lebih dari satu semester ternyata memberikan dampak negatif bagi psikologis siswa. Siswa sudah mulai jenuh dengan sistem pembelajaran daring setelah dua minggu pertama belajar dari rumah, perubahan perasaan menjadi malas dan tidak berminat belajar terjadi karena terlalu banyak tugas yang dianggap tidak efektif oleh siswa. Siswa juga tidak mampu memahami materi secara utuh karena terbatasnya komunikasi yang terjadi dengan guru selama pembelajaran daring (Irawan et al., 2020; Jariyah \& Tyastirin, 2020; Wijaya et al., 2020).

Selain dampak psikologis, pembelajaran daring dengan media laptop dan atau telepon selular juga menimbulkan kecemasan yang cukup besar khususnya pada orang tua siswa berpenghasilan rendah, karena harus membeli telepon selular baru dan kuota internet agar siswa dapat berpartisipasi dalam pembelajaran (Irawan et al., 2020; Jariyah \& Tyastirin, 2020).

Dampak negatif ini diduga timbul akibat akumulasi kendala yang tidak mampu ditangani oleh siswa, guru, sekolah serta orang tua sebagai komponen inti proses pembelajaran. Kendala teknis yang paling utama yakni terbatasnya kuota internet sebagai modal utama untuk ikut dalam pembelajaran daring serta stabilitas jaringan internet yang buruk khususnya di kawasan-kawasan pinggiran kota dan pedesaan (Fauzi \& Khusuma, 2020; Rigianti, 2020; W. Sari et al., 2020).

Selain kendala teknis yang dirasakan oleh siswa, pelayanan yang kurang maksimal dari tenaga pengajar juga menjadi rintangan selama pembelajaran daring. Para guru yang terbiasa menggunakan gaya mengajar konvensional seperti ceramah, diskusi kelompok dan penugasan langsung pada pembelajaran tatap muka, merasa bahwa mekanisme daring secara penuh kurang memberikan kepuasan dalam mengajar (Fauzi \& Khusuma, 2020; Hutauruk $\&$ Sidabutar, 2020; Rigianti, 2020).

Proses pembelajaran daring yang telah berjalan dirasa kurang sesuai untuk siswa pada tingkat usia dini dan kelas bawah pada pendidikan dasar karena siswa masih belum mandiri secara psikologis. Pembelajaran daring justru menghilangkan esensi pada proses internalisasi pengetahuan siswa yang masih membutuhkan pendampingan tenaga pendidik sebagi pengganti orang tua yang sibuk bekerja (Anggianita et al., 2020; Dewi, 2020; Muhdi et al., 2020).

Dampak negatif pada psikologis siswa akibat pembelajaran daring yang terlalu lama sebenarnya telah disadari dan diakui oleh Menteri Pendidikan dan Kebudayaan, Nadiem Makarim. Namun demikian, pemerintah tidak memiliki pilhan lain karena prioritas pada masa pandemi covid-19 ini adalah kesehatan dan keselamatan siswa dan guru (Suciatiningrum, 2020). 
Merujuk pada berbagai hasil penelitian tersebut, artikel ini berupaya untuk melakukan kajian evaluatif terhadap proses pembelajaran daring di Indonesia yang telah berlangsung sejak Maret 2020 hingga sekarang. Evaluasi didasarkan pada berbagai temuan atau hasil penelitian relevan yang telah dipublikasikan dalam jurnal ilmiah. Tujuan utama penulisan artikel ini yakni mendeskripsikan hasil tinjauan terhadap proses pembelajaran daring sehingga dapat dimanfaatkan oleh pemerintah dan praktisi pendidikan dalam menyusun strategi pembelajaran daring jika memang masih akan diterapkan pada tahun ajaran 2021/2022.

Nilai kebaruan (novelty) pada kajian ini yakni penulis memperluas tinjauan evaluasi pada aspek tantangan pembelajaran daring dan peluang pelaksanaan pembelajaran daring untuk terus dilaksanakan. Aspek-aspek ini yang belum penulis temukan pada artikel-artikel sebelumnya.

\section{METODE PENELITIAN}

Metode penelitian yang digunakan untuk menulis artikel ini yakni metode studi kepustakaan. Menurut Sugiyono, studi kepustakaan berkaitan dengan kajian teoritis dan referensi lain yang berkaitan dengan nilai, budaya dan norma yang berkembang pada situasi sosial yang diteliti (Sugiyono, 2011). Sumber data dalam kajian ini adalah artikel ilmiah yang telah dipublikasikan dalam jurnal ilmiah dengan kata kunci "pembelajaran daring masa pandemi covid-19”. Teknik analisis data menggunakan pendekatan kualitatif deskriptif yang terdiri atas tahap mereduksi data, menyajikan data dan membuat kesimpulan (Sugiyono, 2011).

Pada tahap mereduksi data, penulis membuat kategorisasi terhadap data yang telah terkumpul menjadi beberapa kelompok data yakni: 1) kelompok data yang memuat hasil penelitian tentang dampak positif pembelajaran daring; 2) kelompok data yang memuat hasil penelitian tentang dampak negatif sistem pembelajaran daring; 3) kelompok data yang memuat hasil penelitian tentang tantangan pembelajaran daring; 4) kelompok data yang memuat hasil penelitian tentang peluang keberlanjutan pembelajaran daring.

Setelah melewati tahap reduksi, data penelitian kemudian disajikan dalam bentuk deskripsi (data display) untuk dilanjutkan pada tahap berikutnya yakni penarikan kesimpulan/ verifikasi (conclusion/ verification). Tahapan pengolahan dan analisis ata digambarkan dalam skema berikut:

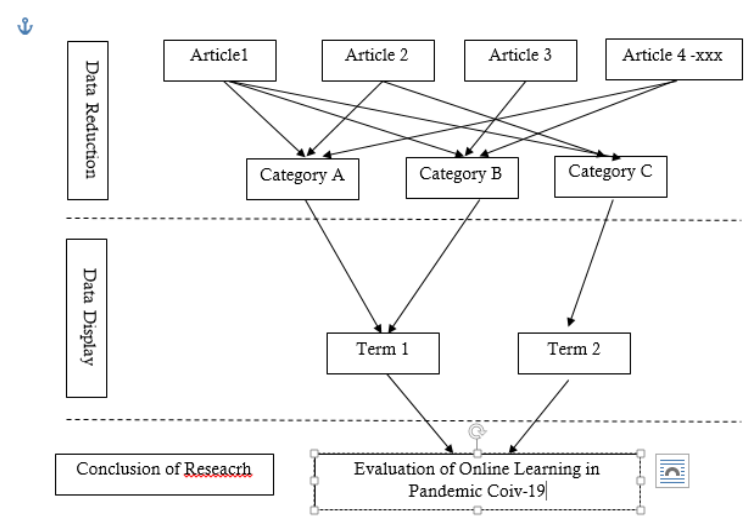

Gambar 1. Tahap analisis data

\section{HASIL DAN PEMBAHASAN}

\section{Dampak Positif Pembelajaran Daring}

Sistem pembelajaran dalam jaringan (daring) yang memanfaatkan media komputer 
dan telepon seluler sebenarnya sudah lama diterapkan dalam proses pembelajaran jarak jauh (PJJ) terutama pada jenjang pendidikan tinggi di Universitas Terbuka. Namun, penerapannya di jenjang pendidikan dasar dan menengah baru intensif pada masa Pandemi covid-19 ini. Sistem pembelajaran daring memungkinkan siswa dan guru tetap dapat menjalani kegiatan belajar-mengajar meskipun berbeda tempat dan waktu. Guru dan siswa tetap dapat berinteraksi dalam proses pembelajaran melalui perangkat dan bantuan aplikasi pembelajaran meskipun tidak sedang bersama dalam satu ruang kelas. Siswa tetap dapat mengakses materi pelajaran yang telah disiapkan oleh guru, meskipun tidak pada jadwal pelajaran yang ditetapkan. Dampak positif bagi siswa yakni adanya kebebasan waktu dan gaya belajar yang dirasa cocok bagi mereka. Siswa dapat lebih aktif mencari materi dari berbagai sumber belajar yang tersedia di internet, baik sebagai sumber primer, bahan pengaya maupun sebagai referensi saat mengerjakan tugas sekolah sehingga tidak tergantung pada referensi yang digunakan oleh guru. Siswa dapat mandiri dalam mengatur jadwal belajar, lebih bertanggung jawab untuk menyelesaikan tugas-tugas yang diberikan, lebih kreatif dan inovatif dalam mencari solusi ketika menghadapi kendala selama proses pembelajaran. Sistem pembelajarn daring mempermudah penerapan prinsip student learning centre (Schaefer et al., 2020).

\section{Dampak Negatif Pembelajaran Daring}

Berbagai kendala selama proses pembelajaran daring yang tidak mampu diselesaikan oleh siswa, guru dan orang tua dapat membawa dampak negatif bagi perkembangan psikologi dan kompetensi siswa. Kajian terhadap artikel penelitian yang relevan menunjukkan bahwa kendala utama yakni pada sarana penunjang pembelajaran daring. Tidak semua orang tua siswa mampu menyediakan telepon seluler sebagai media pembelajaran daring bagi anaknya. Meskipun orang tua mampu membeli perangkat tersebut, ketersediaan kuota internet menjadi kendala berikutnya. Selama masa pandemi covid-19, sektor ekonomi mengalami kekacauan yang berakibat pada menurunnya pendapatan masyarakat secara makro. Kondisi ini akan menjadi beban psikologis tersendiri bagi siswa dari kalangan menengah ke bawah karena tidak dapat berpartisipasi dalam pembelajaran. Banyak laporan menunjukkan bahwa kendala teknis ini menjadi penyebab menurunnya minat belajar siswa yang ditunjukkan dengan kurangnya antusisme siswa dalam grup diskusi via aplikasi bertukar pesan, rendahnya angka partisipasi siswa dalam mengumpulkan tugas, serta peningkatan jumlah siswa yang tidak mengikuti kelas secara virtual (Adnan \& Anwar, 2020; Fauzi \& Khusuma, 2020; Irawan et al., 2020; Jariyah \& Tyastirin, 2020; Rigianti, 2020; Wijaya et al., 2020).

Dampak negatif pembelajaran daring lebih dirasakan oleh siswa usia dini dan siswa jenjang sekolah dasar. Secara psikologi siswa belum mampu memanfaatkan telepon seluler secara bijak sehingga perlu didampingi secara penuh oleh orang tua selama proses pembelajaran. Namun demikian, tidak semua 
orang tua dapat menjadi pendamping sekaligus pembimbing yang optimal bagi siswa akibat kesibukan pekerjaan mereka. Selain itu, siswa usia dini dan siswa SD kelas rendah masih berorientasi pada gaya pembelajaran kinestetik (gerak tubuh) sehingga mereka lebih cenderung mudah memahami jika mereka mempraktikkan langsung hal yang sedang dipelajari. Proses penduplikasian informasi ini tidak akan optimal jika dilaksanakan dengan mekanisme daring (Anggianita et al., 2020; Dewi, 2020; Muhdi et al., 2020; Sari et al., 2021).

Dampak negatif akibat kendala teknis ini juga dirasakan oleh guru. Perubahan mekanisme dan budaya pembelajaran dari konvensional menjadi pembelajaran daring yang berlangsung secara tiba-tiba dan wajib dilaksanakan mengakibatkan banyak guru mengalami cultural shock, terlebih bagi guru yang masih gagap teknologi. Perubahan yang terlalu cepat berdampak pada ketidakselarasan kegiatan perencanaan, proses pembelajaran dan kegiatan evaluasi yang telah dirancang guru. Implikasi dari kendala ini yakni proses pembelajaran daring menjadi sangat monoton dan tidak bermakna. Kegiatan mengajar yang dilaksanakan guru terbatas pada mengunggah materi, meminta siswa mempelajari materi tersebut secara mandiri atau berkelompok dan kemudian memberikan tugas sebagai bahan evaluasi ketercapaian standar kompetensi pada materi yang diajarkan (Fauzi \& Khusuma, 2020; Hutauruk \& Sidabutar, 2020; Rigianti, 2020).

\section{Tantangan Pembelajaran Daring}

Tantangan yang dihadapi siswa dan guru selama proses pembelajaran daring meliputi ketersediaan sarana pembelajaran yang memadai, kondisi psikologis siswa, dan pengalaman guru saat mengajar daring. Pada kenyataannya, tidak semua orang tua siswa memiliki kemampuan menyediakan laptop dan telepon seluler sebagai sarana utama proses pembelajaran. Ketersediaan kuota internet dan sinyal internet yang buruk terutama di wilayah pedesaan juga menjadi bagian dari tantangan teknis pembelajaran daring. Tantangan lain yakni kondisi psikologis dan motivasi belajar. Pembelajaran daring dari rumah berpotensi membuat siswa sulit berpartisipasi dalam kegiatan pembelajaran akibat lingkungan yang tidak kondusif sehingga siswa tidak fokus belajar. Selain itu, keterbatasan guru dalam memantau aktivitas siswa cenderung membuka celah bagi siswa untuk melakukan kegiatan lain selama proses pembelajaran berlangsung sehingga perhatian siswa teralihkan pada hal tersebut (Baber, 2020; Rasmitadila et al., 2020).

Hasil penelitian Sutarto dan Allo menunjukkan bahwa pembelajaran daring juga menjadi tantangan bagi guru untuk mampu menyusun strategi pengajaran yang tepat untuk membangkitkan minat dan motivasi belajar siswa, memberikan pemahaman kepada siswa tentang pentingnya tetap belajar meskipun dari rumah, membuat materi pembelajaran yang singkat dan padat dengan menggunakan media pembelajaran yang menarik, serta melakukan evaluasi secara berkala dan berkesinambungan (Allo, 2020; Sutarto et al., 2020). 
Strategi pembelajaran yang tepat merupakan tantangan utama bagi para guru untuk mengurangi rasa jenuh siswa selama proses pembelajaran daring. Guru dapat mencoba berbagai model pembelajaran berbasis cooperative learing $(C L)$ yang mudah diaplikasikan siswa di rumah masing-masing sesuai konteks/ materi ajar. Strategi lain yakni dengan menerapkan project base learning $(P B L)$ guna membangkitkan minat, rasa ingin tahu, kreativitas dan kerja sama antar siswa dalam satu tim untuk menyelesaikan proyek yang ditugaskan. Strategi CL dan PBL ini tetap harus memperhatikan kondisi umum siswa yang menjadi subjek pembelajar sehingga dapat berjalan efektif.

\section{Peluang Keberlanjutan Pembelajaran Daring}

Tinjauan terhadap dampak positif dan negatif selama proses pembelajaran daring menunjukkan bahwa mekanisme ini dapat tetap dilaksanakan dengan terus melakukan berbagai upaya untuk meminimalisir kendala teknis, menekan biaya operasional, pembiasaan siswa dan meningkatkan kompetensi guru sebagai fasilitator pembelajaran. Pembelajaran daring tetap dapat dilanjutkan meski pandemi covid19 telah selesai dan kegiatan belajar di sekolah sudah kembali seperti semula. Perpaduan mekanisme pembelajaran konvensional dan daring (blended learning) yang tepat dapat memberikan hasil optimal terhadap kualitas proses dan hasil belajar siswa (Adedoyin \& Soykan, 2020; Alqahtani \& Rajkhan, 2020; Bahasoan et al., 2020).
Pelaksanaan pembelajaran daring yang dipadukan dengan pembelajaran konvensional akan menjadi sangat efektif jika memenuhi empat komponen esensial dalam pembelajaran yaitu diskursif, adaptif, interaktif dan reflektif. Diskursif, yakni proses pembelajaran harus mampu mengembangkan kemampuan nalar siswa. Adaptif, yakni materi pembelajaran harus fleksibel terhadap kondisi kekinian dan lingkungan sosial siswa. Interaktif, yakni proses yang terjadi sebagai akibat komunikasi multi arah antara siswa dengan siswa maupun siswa dengan guru. Reflektif, yakni proses pembelajaran yang berlangsung harus mampu meningkatkan kemampuan dan keterampilan siswa dalam memecahkan masalah yang dihadapi secara kritis dan kreatif dengan modal pengetahuan yang dimiliki. Komponen esensial yang diintegrasikan dengan kondusifitas lingkungan belajar akan membentuk digital learning ecosystem. Ekosistem belajar berbasis digital ini menjadi peluang peningkatan kualitas proses dan hasil belajar karena mampu mengakomodir gaya belajar, fleksibilitas dan pengalaman belajar peserta didik (Oktavian \& Aldya, 2020).

\section{SIMPULAN}

Simpulan dalam penelitian ini bahwa mekanisme pembelajaran daring memiliki dampak positif berupa kemandirian siswa dalam belajar, peningkatan aktivitas mencari sumber belajar dan inovasi gaya belajar. Adapun dampak negatif berupa penurunan intensitas siswa dalam belajar sebagai akumulasi dari rasa jenuh, kurang berinteraksi 
dengan teman sebaya dan gangguan pada jaringan atau media pembelajaran. Tantangan yang dihadapi oleh siswa dan guru selama pembelajaran daring yakni ketersediaan sarana penunjang, strategi pembelajaran yang inovatif dan sinergisitas antara komponen pendidikan. Pembelajaran daring berpeluang untuk terus dilaksanakan dengan sistem blended learning guna menciptakan ekosistem pembelajaran digital yang efektif dan efisien

\section{DAFTAR RUJUKAN}

Adedoyin, O. B., \& Soykan, E. (2020). Covid19 pandemic and online learning: the challenges and opportunities. Interactive Learning Environments, O(0), 1-13. https://doi.org/10.1080/10494820.2020.1 813180

Adnan, M., \& Anwar, K. (2020). Online learning amid the COVID-19 pandemic: Students' perspectives. Journal of Pedagogical Sociology and Psychology, 2(1), 133-139. https://doi.org/10.46627/silet.v1i3.46

Allo, M. D. G. (2020). Is the online learning good in the midst of Covid-19 Pandemic? The case of EFL learners. Jurnal Sinestesia, 10(1), 1-10.

Alqahtani, A. Y., \& Rajkhan, A. A. (2020). Elearning critical success factors during the covid-19 pandemic: A comprehensive analysis of e-learning managerial perspectives. Education Sciences, 10(9), $1-16$.

https://doi.org/10.3390/educsci10090216

Anggianita, S., Yusnira, Y., \& Rizal, M. S. (2020). Persepsi Guru terhadap Pembelajaran Daring di Sekolah Dasar Negeri 013 Kumantan. Journal of Education Research, 1(2), 177-182. https://doi.org/10.37985/joe.v1i2.18

Baber, H. (2020). Determinants of students' perceived learning outcome and satisfaction in online learning during the pandemic of COVID19. Journal of Education and E-Learning Research, 7(3), 285-292. https://doi.org/10.20448/JOURNAL.509. 2020.73.285.292

Bahasoan, A. N., Ayuandiani, W., Mukhram, M., \& Rahmat, A. (2020). Effectiveness of Online Learning In Pandemic Covid19. International Journal of Science, Technology \& Management, 1(2), 100106.

https://doi.org/10.46729/ijstm.v1i2.30

Bari, S. (2020). PANDUAN PEMBELAJARAN JARAK JAUH Bagi Guru selama Sekolah Tutup dan Pandemi Covid 19 dengan semangat Merdeka Belajar. DIREKTORAT JENDERAL GURU DAN TENAGA KEPENDIDIKAN KEMENTERIAN PENDIDIKAN DAN KEBUDAYAAN 2020.

Covid19.go.id. (2021). Sebaran Kasus Covid19. covid19.go.id

Dewi, W. A. F. (2020). Dampak COVID-19 terhadap Implementasi Pembelajaran Daring di Sekolah Dasar. Edukatif: Jurnal Ilmu Pendidikan, 2(1), 55-61. https://doi.org/10.31004/edukatif.v2i1.89

Fauzi, I., \& Khusuma, I. H. S. (2020). Teachers' Elementary School in Online Learning of COVID-19 Pandemic Conditions. Jurnal Iqra': Kajian Ilmu Pendidikan, 5(1), 58-70. https://doi.org/10.25217/ji.v5i1.914

Giatman, M., Siswati, S., \& Basri, I. Y. (2020). Online Learning Quality Control in the Pandemic Covid-19 Era in Indonesia. Journal of Nonformal Education, 6(2), 168-175.

https://journal.unnes.ac.id/nju/index.php/ jne

Hutauruk, A., \& Sidabutar, R. (2020). Kendala pembelajaran daring selama masa pandemi di kalangan mahasiswa pendidikan matematika: Kajian kualiatatif deskriptif. Journal of Mathematics Education and Applied, 02(01), 45-51.

Irawan, A. W., Dwisona, D., \& Lestari, M. 
(2020). Psychological Impacts of Students on Online Learning During the Pandemic COVID-19. KONSELI : Jurnal Bimbingan Dan Konseling (E-Journal), 7(1), 53-60. https://doi.org/10.24042/kons.v7i1.6389

Jariyah, A., \& Tyastirin, E. (2020). Proses dan Kendala Pembelajaran Biologi di Masa Pandemi Covid-19: Analisis Respon Mahasiswa The Biology Learning Processes and Constraints in the Covid-19 Pandemic Period: Analysis of Student Responses. Jurnal Penelitian Dan Pengkajian Ilmu Pendidikan: E-Saintika, 4(2), 183-196.

Kemendikbud. (2020). Mendikbud Terbitkan SE tentang Pelaksanaan Pendidikan dalam Masa Darurat Covid-19. Kementrian Pendidikan Dan Kebudayaan Nasional.

https://www.kemdikbud.go.id/main/blog/ 2020/03/mendikbud-terbitkan-setentang-pelaksanaan-pendidikan-dalammasa-darurat-covid19

Muhdi, Nurkolis, \& Yuliejantiningsih, Y. (2020). The Implementation of Online Learning in Early Childhood Education During the Covid-19 Pandemic. JPUD Jurnal Pendidikan Usia Dini, 14(2), 247261. https://doi.org/10.21009/jpud.142.04

Nuraini, R. (2020). Kasus Covid-19 Pertama, Masyarakat Jangan Panik. Indonesia.Go.Id: Portal Informasi Indonesia. https://indonesia.go.id/narasi/indonesiadalam-angka/ekonomi/kasus-covid-19pertama-masyarakat-jangan-panik

Oktavian, R., \& Aldya, R. F. (2020). Efektivitas Pembelajaran Daring Terintegrasi di Era Pendidikan 4.0. Didaktis: Jurnal Pendidikan Dan Ilmu Pengetahuan, 20(2), 129-135. https://doi.org/10.30651/didaktis.v20i2.4 763

Rasmitadila, Aliyyah, R. R., Rachmadtullah, R., Samsudin, A., Syaodih, E., Nurtanto, M., \& Tambunan, A. R. S. (2020). The perceptions of primary school teachers of online learning during the covid-19 pandemic period: A case study in Indonesia. Journal of Ethnic and Cultural Studies, $\quad 7(2), \quad 90-109$. https://doi.org/10.29333/ejecs/388

Rigianti, H. A. (2020). Kendala Pembelajaran Daring Guru Sekolah Dasar di Kabupaten Banjarnegara. Elementary School: Jurnal Pendidikan Dan Pembelajaran Ke-SDAn, 7(2), 297-302.

Sari, R. P., Tusyantari, N. B., \& Suswandari, M. (2021). Dampak Pembelajaran Daring Bagi Siswa Sekolah Dasar Selama Covid19. Prima Magistra: Jurnal Ilmiah Kependidikan, 2(1), 9-15. https://doi.org/https://doi.org/10.37478/jp m.v2i1.732

Sari, W., Rifki, A. M., \& Karmila, M. (2020). Pembelajaran Jarak Jauh Pada Masa Darurat Covid 19. Jurnal MAPPESONA, 1,12 .

Schaefer, M. B., Abrams, S. S., Kurpis, M., Abrams, M., \& Abrams, C. (2020). "Making the Unusual Usual:" Students' Perspectives and Experiences of Learning at Home during the COVID-19 Pandemic. Middle Grades Review, 6(2), 8.

Simamora, R. M. (2020). The Challenges of Online Learning during the COVID-19 Pandemic: An Essay Analysis of Performing Arts Education Students. Studies in Learning and Teaching, 1(2), 86-103. https://doi.org/10.46627/silet.v1i2.38

Suciatiningrum, D. (2020). Mendikbud Nadiem Ungkap Dampak Negatif Belajar Daring. IDN Times. https://kaltim.idntimes.com/news/indone sia/dini-suciatiningrum/mendikbudnadiem-ungkap-dampak-negatif-belajardaring-pada-anak-regional-kaltim/1

Sugiyono. (2011). Metode Penelitian Kuantitatif Kualitatif dan $R \& D$ (14th ed.). Alfabeta.

Sutarto, S., Sari, D. P., \& Fathurrochman, I. (2020). Teacher strategies in online learning to increase students' interest in learning during COVID-19 pandemic. 
Jurnal Konseling Dan Pendidikan, 8(3), 129. https://doi.org/10.29210/147800

Wijaya, T. T., Ying, Z., Purnama, A., \& Hermita, N. (2020). Indonesian students' learning attitude towards online learning during the coronavirus pandemic. Psychology, Evaluation, and Technology in Educational Research, 3(1), 17-25. https://doi.org/10.33292/petier.v3i1.56 